\title{
RANCANGAN DAN PENGGUNAAN SISTEM STUDENT INTERSHIP MONITORING APPLICATION (SIMA) UNTUK MANAJEMEN PROGRAM PRAKTEK PENGALAMAN LAPANGAN
}

\author{
Gerlan Apriandy Manu \\ Universitas Citra Bangsa, Propinsi Nusa Tenggara Timur
}

gerlan.manu@gmail.com

\begin{abstract}
ABSTRAK
Perkembangan teknologi yang berkembang saat ini sangat mendukung dalam proses pengawasan (monitoring) mahasiswa Praktek Pengalaman Lapangan (PPL). Monitoring Program PPL pada Universitas Citra Bangsa dilakukan oleh Fakultas Keguruan dan Ilmu Pendidikan (FKIP) dilaksanakan masih dalam bentuk konvensional. Mahasiswa belum terkontrol secara langsung oleh Dosen Pembimbingnya. Sebagian besar mahasiswa yang ditempatkan di sekolah mitra dikontrol dan diawasi oleh Guru Pamong secara rutin. Dosen Pembimbing hanya sewaktu-waktu melakukan pengontrolan ke sekolah mitra. Oleh karena itu peneliti merasa perlu untuk mengembangkan sistem informasi yang dapat mengontrol dan mengawasi proses bisnis Praktek Pengalaman Lapangan yang disebut Student Intership Monitoring Application (SIMA). Metode penelitian yang digunakan adalah metode penelitian deskriptif dan metode pengumpulan data dengan teknik observasi dan wawancara. Metode pengembangan sistem menggunakan metode prototype. Desain perancangan sistem menggunakan Unified Modelling Language (UML) berupa Use Case Diagram. Hasil penelitian menunjukkan bahwa SIMA dapat melakukan pengontrolan dan pengawasan proses bisnis Praktek Pengalaman Lapangan di FKIP Universitas Citra Bangsa. Dengan SIMA dapat membagi Dosen Pembimbing dan Guru Pamong per mahasiswa PPL. Mahasiswa PPL dapat melaporkan kegiatan rutin ke sistem untuk diawasi dan dikontrol oleh para Dosen Pembimbing maupun Guru Pamong. Manajemen PPL dapat berlangsung dengan baik yang melibat interaksi antara mahasiswa, guru pamong, dosen pembimbing, bag keuangan, pimpinan program studi dan pimpinan fakultas.
\end{abstract}

Kata Kunci : Praktek Pengalaman Lapangan, Sistem Monitoring, Sistem Informasi.

\section{PENDAHULUAN}

Program Pengalaman Lapangan (PPL) menurut Universitas Citra Bangsa adalah salah satu kegiatan kurikuler yang merupakan kulminasi dari seluruh program pendidikan yang telah dihayati dan dialami oleh mahasiswa di lingkungan Fakultas Keguruan dan Ilmu Pendidikan (FKIP) Universitas Citra Bangsa. PPL sebagai ajang pelatihan untuk menerapkan berbagai pengetahuan, sikap, dan keterampilan dalam rangka pembentukan guru yang professional [1]. Mahasiswa FKIP pada tingkat semester VII yang telah memenuhi persyaratan untuk mengikuti PPL dapat mendaftarkan diri dan dilakukan pembekalan sebagai persiapan PPL. Mahasiswa FKIP yang melakukan PPL akan ditempatkan pada sekolahsekolah mulai dari tingkat Sekolah Dasar (SD), Sekolah Menengah Pertama (SMP) dan Sekolah Menengah Atas (SMA). Selama proses PPL mahasiswa dibimbing oleh Guru Pamong dari pihak sekolah dan 
Dosen Pembimbing dari Fakultas. Guru Pamong berkoordinasi dengan Dosen Pembimbing terkait kegiatan PPL yang dilakukan di sekolah. Masa PPL kurang lebih berlangsung selama 3 bulan, dengan waktu disesuaikan dengan waktu kerja pada setiap sekolah. Pada akhir masa PPL akan dilakukan pengujian berupa ujian praktek mengajar di kelas yang akan dinilai oleh Dosen Pembimbing dan Guru Pamong.

Pengawasan (monitoring) proses pelaksanaan PPL selama ini kurang terkontrol dengan baik, kegiatan PPL yang dilakukan mahasiswa FKIP Universitas Citra Bangsa di sekolah-sekolah mitra sejauh ini hanya didominasi oleh bimbingan dari Guru Pamong di setiap sekolah mitra. Koordinasi antara Dosen Pembimbing dan Guru Pamong masih belum maksimal dilakukan. Proses pembimbingan Mahasiswa PPL dengan Dosen Pembimbing sejauh ini tidak terjadi secara rutin selama masa PPL berlangsung. Dan tidak adanya pencatatan proses pembimbingan mahasiswa PPL dengan Dosen Pembimbing juga dengan Guru Pamong.

Berdasarkan ulasan permasalahan tersebut diatas maka perlu dibuatkan suatu sistem atau aplikasi pengawasan kegiatan Program Praktek Lapangan yang dilakukan oleh FKIP Universitas Citra Bangsa. Dalam penelitian ini akan dibahas perancangan Student Intership Monitoring Application (SIMA) Berbasis Web.

\section{METODE PENELITIAN}

\section{a. Metode Deskriptif}

Metode Penelitian yang digunakan dalam penelitian ini adalah metode deskriptif. Pengertian metode deskriptif adalah penelitian yang dilakukan untuk mengetahui nilai masing-masing variabel, baik satu variabel atau lebih sifatnya independen tanpa membuat hubungan maupun perbandingan dengan variabel yang lain[2]. Penelitian deskriptif juga merupakan penelitian yang dilakukan dengan tujuan utama untuk memberikan gambaran atau deskripsi tentang suatu keadaan secara objektif [3].

Dalam penelitian ini, metode deskriptif digunakan untuk menjelaskan tentang proses bisnis dalam manajemen Program Praktek Pengalaman Lapangan (PPL) di Fakultas Keguruan dan Ilmu Pendidikan (FKIP), Universitas Citra Bangsa (UCB).

\section{b. Metode Pengumpulan Data}

Pada penelitian ini peneliti menggunakan metode pengumpulan data dengan cara melakukan observasi, wawancara dan studi pustaka. Pada penelitian ini, observasi dilakukan di FKIP Universitas Citra Bangsa untuk mengamati proses pelaksanaan Program Praktek Lapangan, mulai dari proses penentuan sekolah sebagai tempat praktek, pembekalan, proses pembagian dosen pembimbing, proses pengantaran mahasiswa PPL, proses pembimbingan dengan Guru Pamong, pembimbingan dengan Dosen Pembimbing, proses ujian praktek PPL, pelaporan PPL dan penilaian PPL.

Wawancara dilakukan untuk mengkonfirmasi data atau fakta yang diperoleh pada saat observasi serta sekaligus untuk menggali software requirement dari pengguna. Wawancara dilakukan kepada mahasiswa PPL, Dosen 
Pembimbing dan Guru Pamong sebagai subyek penelitian dari penelitian ini.

Studi pustaka dilakukan untuk mengumpulkan data dan informasi melalui dokumen-dokumen baik dalam bentuk buku, jurnal, prosiding, laporan-laporan, atau bentuk-bentuk lain dalam bentuk tercetak maupun digital.

\section{c. Metode Pengembangan Sistem}

Pada penelitian ini menggunakan Metode Pengembangan Sistem Agile Agile Software Development Methods. Agile Software Development Methods yang digunakan adalah menggunakan Model Scrum. Model Scrum adalah implementasi konkrit dari Metode Agile, dimana motede ini berfokus pada pengembangan sistem yang berulang, dengan hasil yang maksimal dalam waktu yang singkat. Model Scrum berfokus pada software management issue bukan pada teknis pengembangan sistemnya sehingga secara bertahap dapat menghasilkan sistem yang efektif digunakan oleh penggunanya [4]. Model Scrum menggunakan 4 tahap pengembangan sistem yaitu Backlog, Sprints, Scrum, dan Demo[5], yang dalam penelitian ini dijelaskan sebagai berikut:

\section{Backlog}

Peneliti melakukan wawancara terhadap Subyek Penelitian yaitu Mahasiswa PPL, Dosen Pembimbing dan Guru Pamong dan observasi langsung atas proses pelaksanaan Program Praktek Lapangan di lingkungan FKIP Universitas Citra Bangsa. Dari hasil observasi dan wawancara ini dituliskan daftar/rincian prioritas pada fitur-fitur yang perlu ada dalam pengembangan sistem Student Intership Monitoring Application
(SIMA) Berbasis Web yaitu terdapat empat aktifitas utama : Pendaftaran, Penempatan, Proses PPL, dan Ujian Penilaian.

2. Sprints

Peneliti menyusun kegiatan yang akan dilakukan untuk memenuhi kebutuhan yang ditetapkan dalam tahap 1 - backlog. Dalam susunan kegiatan ini dibuatkan jadwal termasuk didalamnya jadwal proses analisa kebutuhan sistem, desain sistem, pembuatan kode sistem (coding), testing, dan support system. Di dalam tahap 2 - Sprints juga dilakukan tracking atau melacak pelaksanaan kegiatan yang telah dijadwalkan. Fokus tahap $2-$ Sprints tetap mengacuh pada empat aktifitas utama yaitu Pendaftaran, Penempatan, Proses PPL, dan Ujian - Penilaian.

3. Scrum Meeting

Menyelenggarakan rapat dengan tim yang telah ditunjuk untuk membahas kemajuan kegiatan pengembangan sistem : Student Intership Monitoring Application (SIMA) Berbasis Web.

4. Demos

Menunjukkan fitur-fitur software yang telah dihasilkan untuk dievaluasi oleh pengguna sesuai dengan waktu yang telah ditentukan. Dalam tahap 4 Demos ini dilakukan presentase (demo) sistem kepada setiap level pengguna sistem.

Pada tahap ke 3 dan ke 4, Pengkodean telah dilakukan menggunakan PHPMaker yang adalah sebuah aplikasi php code generate, yang dapat menghasilkan file .php dengan mudah dan cepat sehingga fokus pembuatan sistem 
mengacuh pada empat aktifitas utama tersebut yaitu Pendaftaran, Penempatan, Proses PPL, dan Ujian - Penilaian.

\section{Dengan PHPMaker dapat} menghasilkan sebuah halaman web berupa list page atau halaman berisi daftar data yang ada pada tabel, add/copy form atau halaman formulir tambah data atau salin data, view page atau halaman melihat suatu rekaman data, edit page atau halaman formulir edit data, delete page atau perintah menghapus data, search page atau halaman pencarian data berdasarkan kolom tertentu, page number - data pada tabel dapat dilihat dalam nomor halaman tertentu, export - memungkinkan data tabel dapat diekpor menjadi file pdf, doc, excel, dan lain sebagainya, import memungkinkan data dapat dimasukkan ke dalam sistem melalui file excel dan phpmaker dapat menghasilkan halaman berisi chart atau diagram. [6]

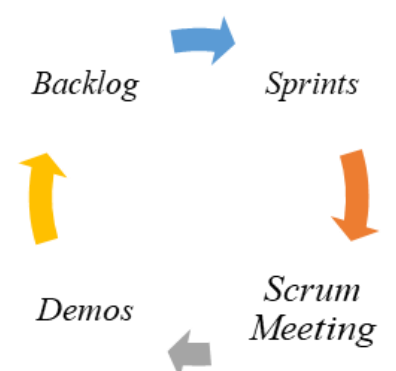

Gambar 1. Model Scrum - Agile Software Development Methods

\section{HASIL DAN PEMBAHASAN}

\subsection{UML (Unifed Modelling Language)}

Perancangan Sistem menggunakan UML (Unifed Modelling Language). UML merupakan sebuah standarisasi bahasa pemodelan untuk pembangunan perangkat lunak yang dibangun dengan menggunakan teknik pemrograman berorientasi objek[7]. Perancangan SIMA menggunakan UML ini tergambar dalam Use Case Diagram dan Activity Diagram.

\subsection{Use Case Diagram dan Activity Diagram}

Pada Use Case Diagram ini terdapat 4 (empat) Aktor yaitu Admin SIMA, Mahasiswa PPL, Guru Pamong dan Dosen Pembimbing. Admin SIMA memiliki akses untuk mengelola sistem yaitu melakukan manajemen user, manajemen data sekolah mitra, data dosen pembimbing, data guru pamong, data mahasiswa PPL, dan penempatan PPL. Untuk Aktor Mahasiswa PPL dapat mengakses Absensi, Log Harian, Kumpul Laporan, Dokumentasi Ujian, Rekap Penilaian, dan Rekap Konsultasi. Untuk Aktor Guru Pamong dan Dosen Pembimbing dapat mengakses Data Penilaian dan Konsultasi.

Mahasiswa PPL dalam mengakses Absensi, dan Log Harian akan dipantau oleh Guru Pamong dan Dosen Pembimbingnya. Setiap kali Mahasiswa PPL melakukan konsultasi secara offline/bertatap muka langsung dengan Dosen Pembimbingnya atau Guru Pamongnya, pada system Guru Pamong dan Dosen Pembimbing perlu memasukan data pada akses Konsultasi agar Admin SIMA dapat melakukan monitoring pembimbingan mahasiswa pada guru pamong dan dosen pembimbingnya masing-masing. Penilaian akan dilakukan setelah Mahasiswa PPL mengumpulkan Laporan dan melakukan ujian PPL di Sekolah. Selesai melakukan Ujian PPL, Mahasiswa PPL perlu menambahkan data Dokumentasi Ujian PPL pada sistem 
dengan mengakses Dokumentasi Ujian (gambar 2)

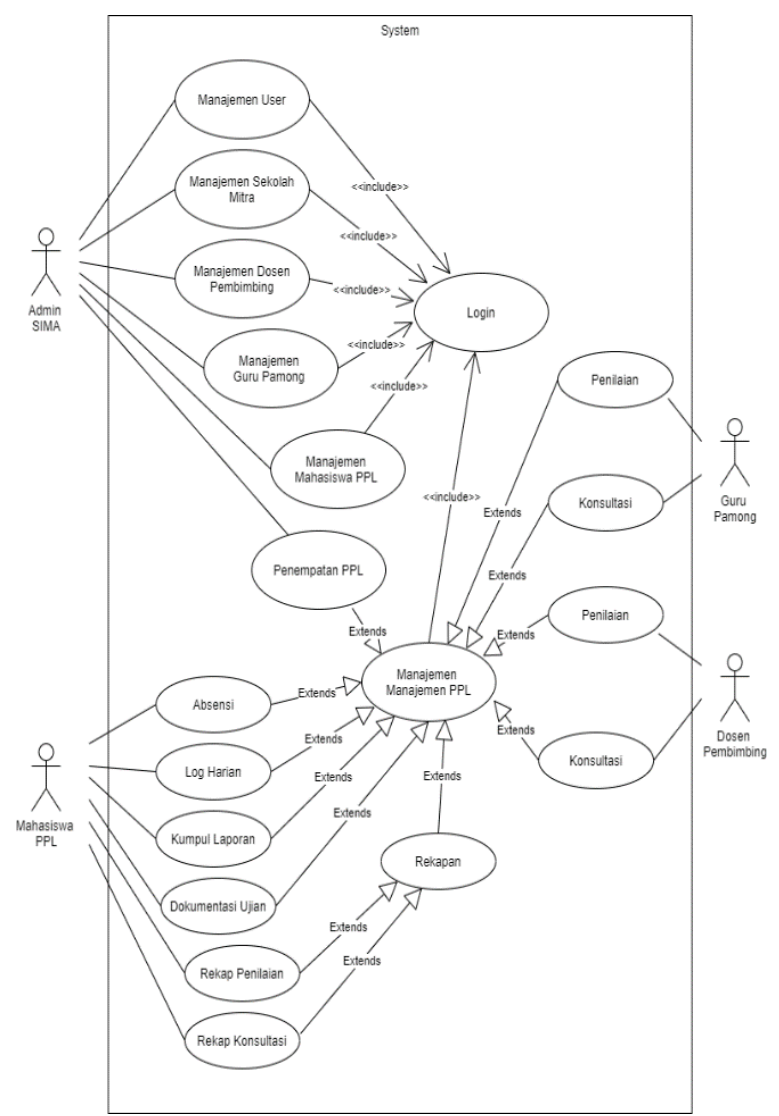

Gambar 2. Use Case Diagram

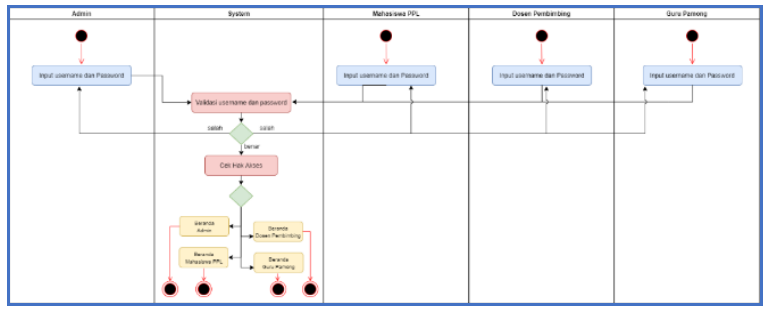

Gambar 3. Activity Diagram - Login

Pada gambar 3 dapat dilihat untuk mengakses sistem, setiap Aktor yaitu Admin SIMA, Mahasiswa PPL, Dosen Pembiming dan Guru Pamong perlu melalukan Login, dengan cara memasukkan username dan password. Sistem kemudian akan melakukan validasi username dan password, jika valid maka akan dilakukan pengecekan hak akses, jika tidak maka Login ditolak. Hak Akses menentukan seorang 21atas/user memiliki akses yang berbeda pada sistem.

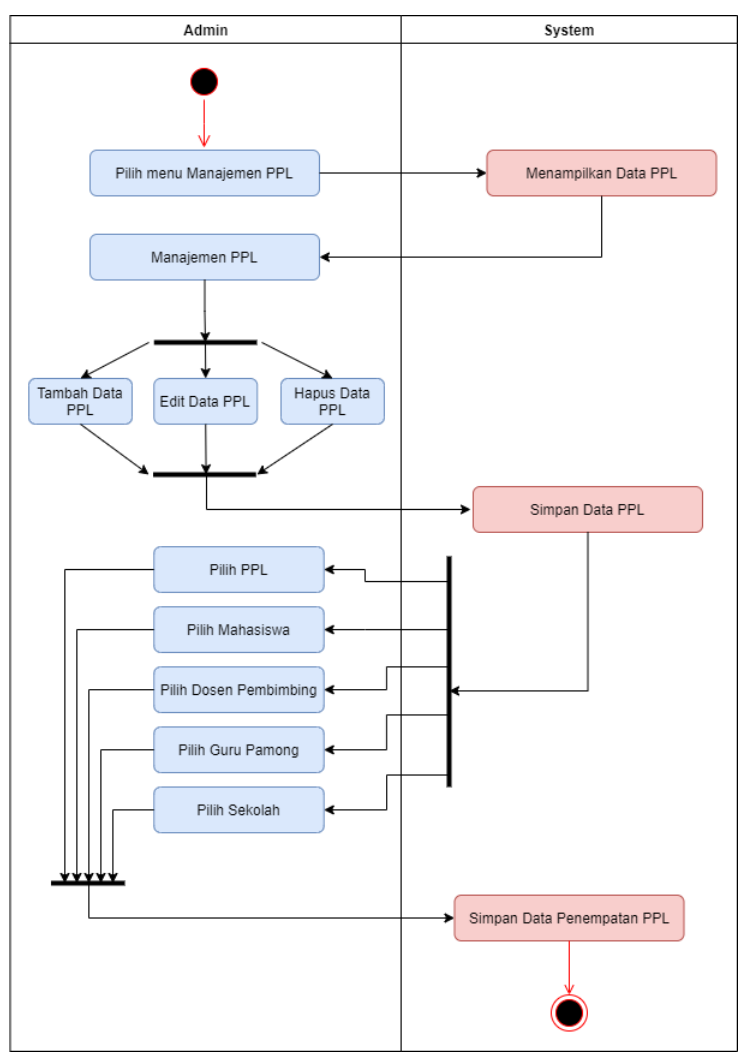

Gambar 4. Activity Diagram-Manajemen $P P L$

Pada gambar 4 dapat dilihat bahwa Admin SIMA mengelola PPL dengan menambahkan data PPL, seperti kapan mulai diadakan PPL, dan kapan selesai PPL dilaksanakan. Kemudian setelah itu Admin SIMA perlu menempatkan mahasiswa PPL pada suatu Sekolah Mitra, berserta dengan siapa Dosen Pembimbingnya dan siapa Guru Pamongnya. Setelah melakukan manajemen PPL ini, barulah, Mahasiswa PPL, Guru Pamong dan Dosen Pembimbing dapat mengakses sistem. 


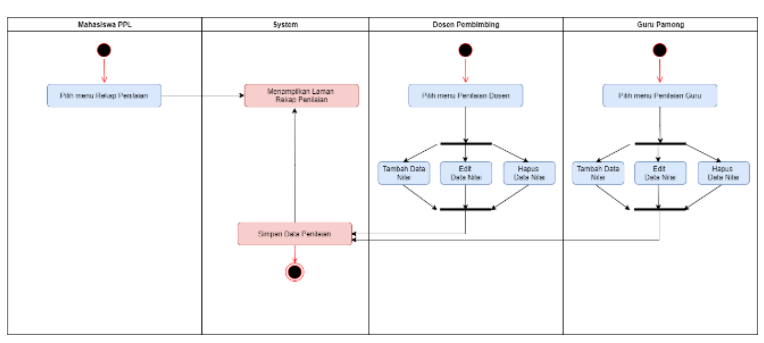

Gambar 5. Activity Diagram - Rekap

\section{Penilaian}

Pada gambar 5 diatas dapat dilihat proses penilaian dilakukan oleh Guru Pamong dan Dosen Penguji, kemudian Rekapan Penilaian dapat dilakukan oleh masing-masing mahasiswa sesuai dengan penetapan Dosen Pembimbing dan Guru Pamong masing-masing mahasiswa tersebut.

\subsection{Relationship Table}

\section{Rancangan}

Database menggunakan Entity Relationship (E-R) Model yaitu representasi grafis dari logika database dengan menyertakan deksripsi detail mengenai seluruh entitas (entity), hubungan (relationship) dan 22atasan (constraint). Diagram E-R merupakan kunci untuk memahami dan membuat desain sebuah database [3].

Diagram ER dari Student Intership Monitoring Application (SIMA) dapat dilihat pada gambar 6 dibawah ini :

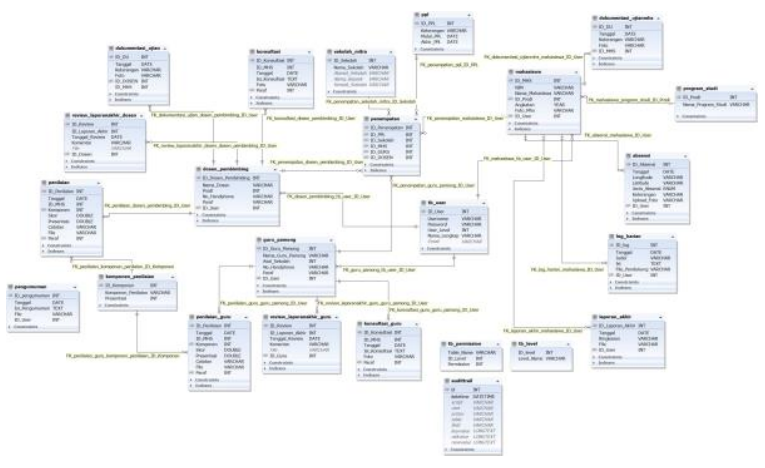

Gambar 6. Relationship Table - Database SIMA

\subsection{Prosedur Penggunaan Sistem}

Student Intership Monitoring Application (SIMA), dapat diakses pada laman https://ppl.citrabangsa.net. Terdapat empat aktifitas utama secara berurut dalam SIMA yaitu Pendaftaran, Penempatan, Proses PPL, dan Ujian - Penilaian. Pada keempat aktifitas utama tersebut masingmasing aktifitas diakses oleh pengguna sistem sesuai dengan hak aksesnya. Penjelasan terhadap empat aktifitas utama ini dapat dilihat pada tabel dibawah ini :

Tabel 1. Aktifitas Utama SIMA

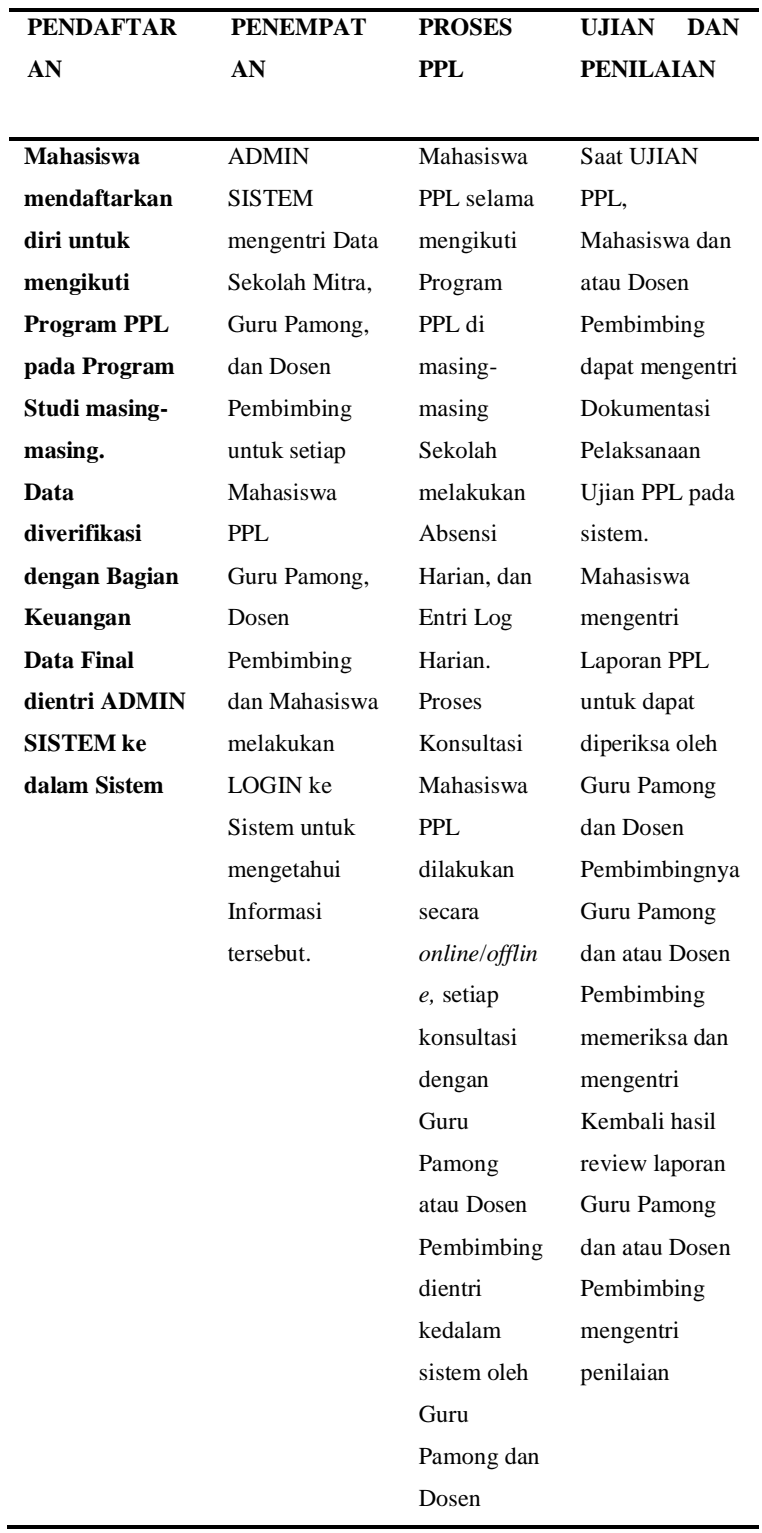


tersebut.

4. Memberikan Pengumuman terkait PPL yang berlangsung

\subsection{Penggunaan Sistem}

\section{a. Akses Administrator}

Dalam manajemen data dan proses pada SIMA dikelola oleh Admin SIMA. Admin SIMA memiliki otoritas tertinggi dalam sistem. Agar sistem dapat diakses dengan baik oleh tiga jenis pengguna lainnya maka Admin SIMA perlu memanajemen data master dan memasukan data PPL setiap tahun ajaran atau setiap Program PPL dimulai.

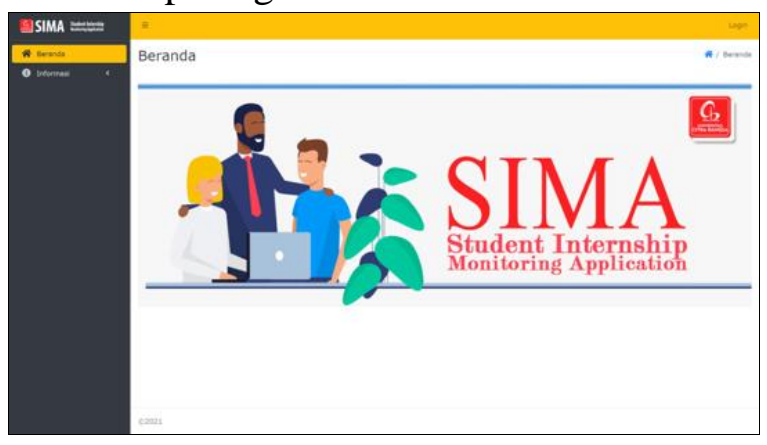

Gambar 7. Halaman Depan SIMA

Administrator Sistem disebut Admin SIMA, memiliki otoritas tertinggi dalam sistem. Terdapat beberapa tugas dari Admin SIMA sebelum sistem dapat digunakan oleh Mahasiswa PPL, Guru Pamong dan Dosen Pembimbing yaitu :

1. Melengkapi Data Master seperti : Data Mahasiswa PPL (beserta dengan akunnya), Data Dosen Pembimbing (beserta dengan akunnya), Data Guru Pamong (beserta dengan akunnya), Data Sekolah Mitra dan Data Program Studi.

2. Mengentri Data PPL

3. Mengatur Penempatan Mahasiswa PPL pada suatu Sekolah Mitra, memilih Guru Pamong, dan Dosen Pembimbing untuk mahasiswa
Setelah Data Master dilengkapi pada tahap selanjutnya Admin Sekolah perlu mengentri masa Pelaksanaan PPL. Kemudian Admin SIMA juga memanajemen penempatan Mahasiswa PPL pada suatu Sekolah. Pada proses penempatan PPL ini, Admin SIMA menempatkan Dosen Pembimbing dan Guru Pamong untuk setiap Mahasiswa PPL (gambar 8 s/d gambar 10).

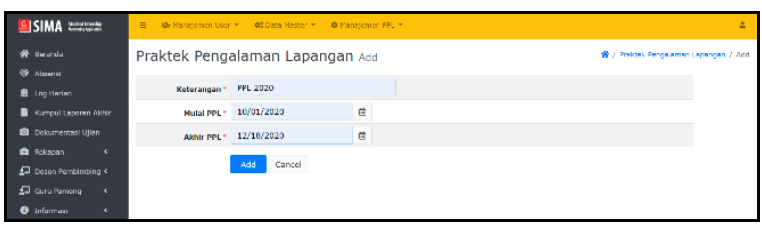

Gambar 8. Menambah Data Praktek Pengalaman Lapangan

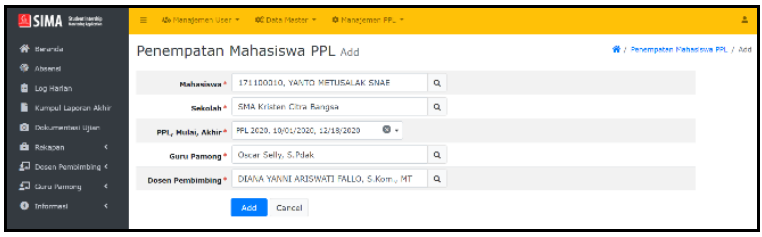

Gambar 9. Menambah Data Penempatan PPL

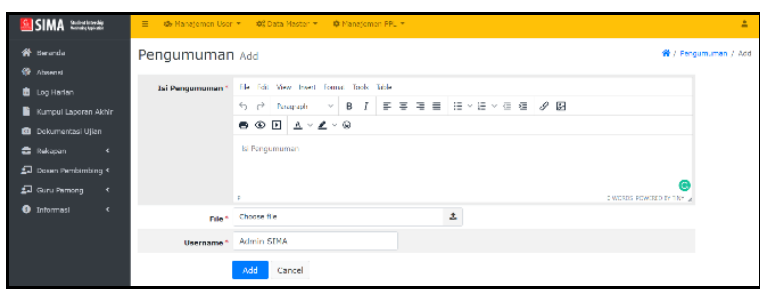

Gambar 10. Menambah Data

Pengumuman

Admin SIMA juga perlu menambah Data Pengumuman pada sistem. Pengumuman yang ditambahkan dapat diakses oleh pengguna biasa (guest), dan juga pengguna dengan otoritas seperti 
mahasiswa PPL, Dosen Pembimbing dan Guru Pamong.

Selain pengaturan awal diatas admin SIMA juga memiliki akses kepada keseluruhan aktifitas sistem yang dientri oleh Mahasiswa PPL, Guru Pamong dan juga Dosen Pembimbing seperti :

1. Profil Mahasiswa

2. Profil Dosen

3. Profil Guru Pamong

4. Absensi Mahasiswa PPL

5. Log Harian Mahasiswa PPL

6. Laporan Akhir PPL

7. Dokumentasi Ujian

8. Konsultasi Guru

9. Konsultasi Dosen

10. Penilaian Guru

11. Penilaian Dosen

\section{b. Akses Mahasiswa}

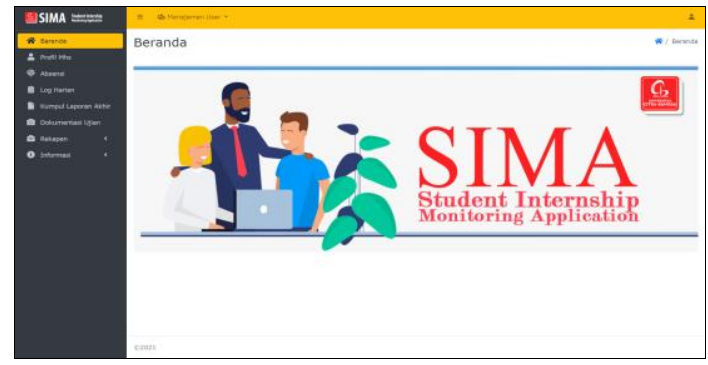

Gambar 11. Halaman Depan - Akses Mahasiswa

Setelah masuk ke sistem, mahasiswa PPL dapat mengubah profilnya masing-masing dengan mengganti foto profil dan informasi lainnya jika ditemukan kesalahan pendataan.

Dalam keseharian di sekolah, mahasiswa PPL wajib melakukan absensi harian sebagai informasi kehadiran. Hal ini akan mempermudah pengontrolan kehadiran oleh Dosen Pembimbing, Guru Pamong dan juga Admin SIMA.

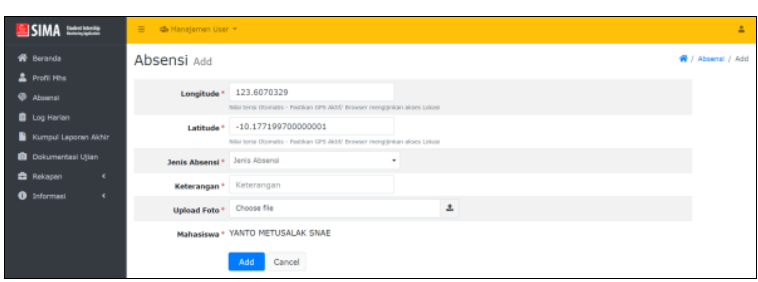

Gambar 12. Halaman Absensi -

Mahasiswa

Pada saat menambahkan data Absensi, sistem akan mendeteksi longitude dan latitude melalui gps gadget yang digunakan. Untuk itu terdapat notifikasi dari sistem untuk meminta izin membaca data gps. Jika mahasiswa tidak mengizinkan maka data absensi tidak dapat dientri. Mahasiswa wajib mengizinkan akses dari sistem untuk membaca data gps tersebut (gambar 12).

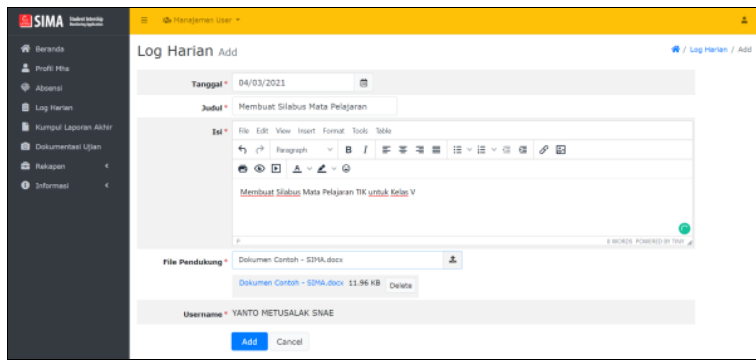

Gambar 13. Halaman Log Harian Mahasiswa

Selain melakukan absensi, mahasiswa PPL perlu menambahkan data Log Harian, sebagai catatan aktifitas keseharian mahasiswa di lokasi Sekolah. Setiap aktifitas yang tercatat ini akan menjadi bahan pertimbangan penilaian oleh Guru Pamong dan Dosen Pembimbing. Mahasiswa dapat menyertakan foto atau dokumen terlampir untuk menunjang catatan/log harian yang dientrinya (gambar 13) 


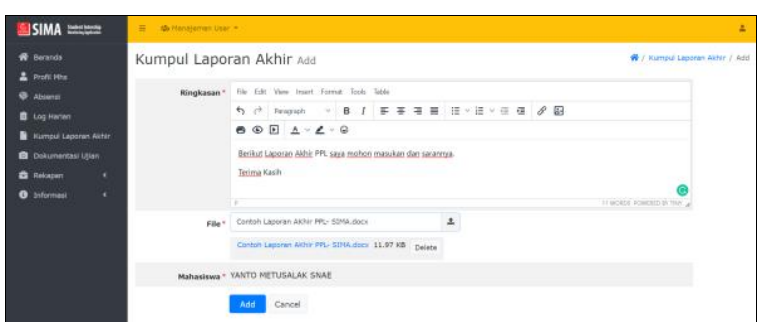

Gambar 14. Halaman Kumpul Laporan

Akhir

Setelah menyelesaikan proses PPL yang berlangsung, mahasiswa dapat melaporkan laporan akhirnya dapat berupa draft atau yang sudah final. Laporan yang dientri akan dilihat oleh Dosen Pembimbing dan atau Guru Pamong untuk diperiksa dan direvisi oleh mahasiswa jika terdapat kekurangan atau penambahan (gambar 14).

\section{c. Akses Guru Pamong dan Dosen Pembimbing}

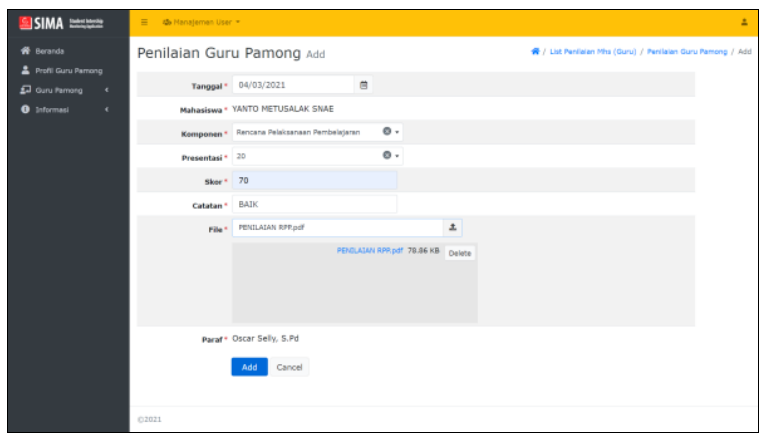

Gambar 15. Halaman Penilaian Mahasiswa Oleh Guru Pamong

Guru Pamong mengakses sistem untuk dapat melihat data mahasiswa bimbingannya, data absensi, data log harian, data konsultasi, dan data laporan ppl yang dikumpulkan mahasiswa bimbingannya. Guru Pamong pada menjelang akhir Program PPL perlu menambahkan data penilaian mahasiswa PPL (gambar 15).

Dosen Pembimbing mempunyai otoritas akses yang sama seperti Guru Pamong, kelebihannya Dosen Pembimbing dapat mengakses penilaian Guru Pamong sebelum memberikan nilai kepada mahasiswa bimbingannya (gambar 16)

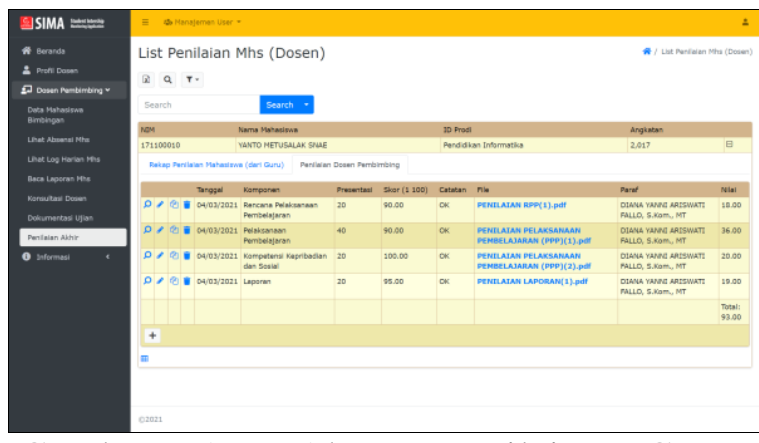

Gambar 16. Akses Penilaian Guru Pamong oleh Dosen Pembimbing

\section{KESIMPULAN}

Penelitian ini menghasilkan sistem monitoring program PPL di FKIP Universitas Citra Bangsa yang dinamakan Student Intership Monitoring Application (SIMA). SIMA dapat diakses oleh Administrator, Mahasiswa PPL, Guru Pamong dan Dosen Pembimbing. Aktifitas Manajemen Program PPL dapat berjalan dengan pengawasan atau monitoring yang baik melalui SIMA.

\section{DAFTAR PUSTAKA}

[1] LP3M Universitas Citra Bangsa, Panduan Program Praktek Pengalaman Lapangan Universitas Citra Bangsa 2020. Kupang: Universitas Citra Bangsa, 2020.

[2] Sugiyono, Metode Penelitian Kuantitatif, Kualitatif dan $R \& D$. Bandung: Alfabeta, 2017.

[3] N. S. Sukmadinata, Metode Penelitian Pendidikan, Cetakan ke. Bandung: Remaja Rosdakarya, 2011.

[4] S. Al-Saqqa, S. Sawalha, dan H. Abdelnabi, "Agile software 
development: Methodologies and trends," Int. J. Interact. Mob.

Technol., vol. 14, no. 11, 2020, doi:

10.3991/ijim.v14i11.13269.

[5] I. Mahendra dan D. T. E. Yanto,

"AGILE DEVELOPMENT

METHODS DALAM

PENGEMBANGAN SISTEM

INFORMASI PENGAJUAN

KREDIT BERBASIS WEB

(STUDI KASUS : BANK BRI

UNIT KOLONEL SUGIONO)," $J$.

Teknol. DAN OPEN SOURCE, vol.

1, no. 2, hal. 13-24, 2018.

[6] G. A. Manu, Program Monitoring

Penelitian Dan Pengabdian

Masyarakat Internal Perguruan

Tinggi Menggunakan PhpMaker

2020. Bandung: Media Sains

Indonesia, 2020.

[7] E. Astriyani, F. N. Putri, dan N. E.

Widianingsih, "Desain Sistem

Informasi Monitoring Aset Pada

PT.Arbunco Wira Pandega," SENSI

J., vol. 6, no. 1, 2020, doi:

10.33050/sensi.v6i1.946. 